\title{
Survival and growth of the Caribbean scallops, Argopecten nucleus and Nodipecten nodosus, in suspended systems at different culture depths and net replacement frequencies
}

\author{
L. A. Velasco*, J. Barros \\ Laboratorio de Moluscos y Microalgas, Universidad del Magdalena, Carrera 32 No 22-08, Santa Marta, Colombia
}

\begin{abstract}
Survival of the Caribbean scallops Argopecten nucleus and Nodipecten nodosus in suspended culture is relatively low. The effects of culture depth and frequency of net replacement on survival and growth of both scallops were assessed, in addition to the effects on the amount of biofouling and presence of predators in the culture systems. Hatchery-produced juveniles were kept in pearl nets suspended at 3 different culture depths $(6,9$ and $12 \mathrm{~m})$ with 2 frequencies for net replacement (i.e. monthly and every second month, hereafter 'bimonthly'). Survival of both scallop species was higher at $12 \mathrm{~m}$ depth. A. nucleus also showed higher growth rates at $12 \mathrm{~m}$ depth, while $N$. nodosus exhibited higher growth rates at $6 \mathrm{~m}$ depth. A. nucleus and $N$. nodosus performed best under monthly and bimonthly net replacement schemes, respectively. Frequency of presence and size of cymatid predators did not differ between treatments, but greater frequency and size of portunids occurred at bimonthly net replacement in A. nucleus culture nets. In most months, the biofouling dry biomass in the pearl nets was higher in those maintained at a depth of $6 \mathrm{~m}$ with bimonthly net replacement. The results indicate that the survival of both scallops could be improved by maintaining the culture systems suspended at a depth of $12 \mathrm{~m}$, under lower temperature conditions, and applying a monthly net replacement scheme in A. nucleus in order to minimize the biofouling on the nets and a bimonthly scheme in $N$. nodosus in order to minimize scallop perturbation associated with net replacement.
\end{abstract}

KEY WORDS: Biofouling $\cdot$ Predators $\cdot$ Bivalves $\cdot$ Epibionts $\cdot$ Temperature $\cdot$ Portunids $\cdot$ Cymatids

\section{INTRODUCTION}

Argopecten nucleus (Born, 1780) and Nodipecten nodosus (Linnaeus, 1758) are pectinid species from the Caribbean, which are cultured at experimental and pilot scale (Velasco \& Barros 2008, Velasco et al. 2011, Valderrama et al. 2016). Both species are epibenthic and live on sandy or calcareous bottom habitats. A. nucleus is a species of moderate size $(\sim 50 \mathrm{~mm})$ occurring over the sea bottom until $50 \mathrm{~m}$ depth, while $N$. nodosus reaches larger sizes $(\sim 150 \mathrm{~mm})$ and lives attached to hard substrates at depths between 10 and 120 m (Díaz \& Puyana 1994, Lodeiros et al. 1999). Both exhibit strong growth in suspended culture systems at low densities (25 to $40 \%$ of bottom net cover-

\footnotetext{
${ }^{*}$ Corresponding author: molmarcol@gmail.com
}

age) at depths between 6 and $32 \mathrm{~m}$, reaching the commercial size $(40 \mathrm{~mm}$ in A. nucleus and $70 \mathrm{~mm}$ in $N$. nodosus) at 9 to 12 mo old (Lodeiros et al. 1998, 2001, Velasco et al. 2009, 2011, 2013, Barros et al. 2018). Their survival, however, is variable and can be rather low: between 7 and $68 \%$ for A. nucleus (Lodeiros et al. 1993, Velasco et al. 2009, Barros et al. 2018) and between 14 and $80 \%$ for $N$. nodosus (Lodeiros et al. 1998, Acosta et al. 2000, Mendoza et al. 2003, Rupp 2007, Velasco et al. 2009, Gómez-León et al. 2010). The main factors related to the low survival of these species are predation, the presence of large amounts of biofouling and high temperatures $\left(>28^{\circ} \mathrm{C}\right.$ ) (Freites \& Núñez 2001, Rupp 2007, Velasco et al. 2009).

(C) The authors 2019. Open Access under Creative Commons by Attribution Licence. Use, distribution and reproduction are unrestricted. Authors and original publication must be credited. 
Some of the main predator species for these scallops in suspended culture systems are portunid crabs (Charybdis hellerii and Cronius ruber) and cymatid snails (Cymatium pileare and $C$. cingulatum) (Freites et al. 2000, Ciocco \& Orensanz 2001, Velasco et al. 2009). Larval states of such organisms enter through the net into the culture systems and rapidly grow at the expense of predating the cultured scallops (Ventilla 1982, Freedman \& Bell 1996). In the case of the biofouling, most of the species found are macroalgae and filtering invertebrates (especially Balanus sp.), which cover the culture systems and, to a lesser degree, the scallop shells (Uribe et al. 2001, Velasco 2008, Cortés-Useche et al. 2011, Carraro et al. 2012). These biofouling species usually compete for resources and restrict the water inflow into the culture systems, and they are also able to parasitize and deteriorate the scallop shells (Lesser et al. 1992, LeBlanc et al. 2002, Pacheco \& Garate 2005, Fitridge et al. 2012). In addition, the presence of biofouling reduces the useful life of the culture systems, and the disposal of used systems in water or on land could impair the environmental quality of marine and terrestrial ecosystems (Uribe et al. 2001, Dürr and Watson 2010, Adams et al. 2011).

Among the mitigation measures used to control biofouling and the presence of predators in the culture systems, some of the most common are physical removal, coating shells and nets with antifouling products, biocontrol and avoidance of natural recruitment (Fitridge et al. 2012). Removal monthly, or every $2 \mathrm{wk}$, of predators and biofouling, as well as the use of sea urchins inside the systems are practices that have been reported as helpful to control the settling of harmful organisms in culture systems of $A$. nucleus and $N$. nodosus at small scales (Velasco et al. 2009, Cortés-Useche et al. 2011). Nevertheless, the use of such practices at a larger scale is considered wasteful, expensive and inconsistent (Roma et al. 2009, Fitridge et al. 2012). Considering that the settling of predator larvae and biofouling is directly influenced by food availability (Pérez et al. 2016), the increase of culture depth could be a useful, cheaper and easier measure to limit the larval recruitment of harmful species, and possibly with less frequent net replacement.

With the goal of identifying operational practices that could improve the productivity of A. nucleus and $N$. nodosus cultured in suspended systems, the present study assessed the effects of culture depth and frequency of net replacement on the survival and growth of both species as well as on the degree of biofouling and presence of predators.

\section{MATERIALS AND METHODS}

A total of 7000 juveniles of Argopecten nucleus (mean \pm SE shell length: $11.3 \pm 0.14 \mathrm{~mm}$ ) and 13200 juveniles of Nodipecten nodosus $(8.5 \pm 0.08 \mathrm{~mm}$ shell length) were produced in the Laboratorio de Moluscos y Microalgas of the Universidad del Magdalena in Taganga, Santa Marta, Colombia $\left(11^{\circ} 16^{\prime} 03^{\prime \prime} \mathrm{N}\right.$, $\left.74^{\circ} 11^{\prime} 24^{\prime \prime} \mathrm{W}\right)$, following the protocols described by Velasco \& Barros (2007, 2008, 2009) and Velasco et al. (2007).

In this study, a factorial experimental design was applied for both species using 3 different culture depths $(6,9$ and $12 \mathrm{~m})$ and 2 frequencies for net replacement (monthly and every 2 mo, hereafter 'bimonthly'), which resulted in 6 treatments with 3 replicates each. Juveniles of each species were randomly distributed in Netlon ${ }^{\circledR}$ pyramidal pearl nets (35 × $35 \times 20 \mathrm{~cm}$ and $6 \mathrm{~mm}$ mesh size) at a stocking density of $30 \%$ of net bottom coverage. The number of scallops placed in each net was calculated on the basis of the area occupied in the bottom of each net $\left(1225 \mathrm{~cm}^{2}\right)$ and the surface area of each specimen assuming a circular shape (387 and 731 ind. net ${ }^{-1}$ for $A$. nucleus and $N$. nodosus, respectively). The pearl nets were then individually suspended in a $100 \mathrm{~m}$ subsurface long-line at a depth of $5 \mathrm{~m}$, leaving $\sim 50 \mathrm{~cm}$ of separation between pearl nets. The long-line system was located in the aquaculture lease of the Universidad del Magdalena in Bahía Taganga (11 $16^{\circ} 04^{\prime \prime} \mathrm{N}$, $\left.74^{\circ} 11^{\prime} 36^{\prime \prime} \mathrm{W}\right)$, where depths varied from 15 to $20 \mathrm{~m}$.

Monthly or bimonthly, depending on the treatment, the pearl nets were taken out of the water and transported ashore for $\sim 4$ to $6 \mathrm{~h}$ in order to replace the nets as well as to estimate scallop growth and survival, the amount of biofouling and the abundance of predators in the nets. For this, the population of each net was transferred to containers (20 to 50 l) with seawater, and the living specimens were counted. Monthly survival for each replica was estimated as the proportion between the number of living bivalves at the end of the month or every second month and the initial number of animals placed in each net. The shell length of 30 randomly selected individuals was measured with calipers $(0.01 \mathrm{~mm})$. Potential predators (crabs and snails) that were present in culture nets were placed in plastic bags containing $4 \%$ seawater formalin for subsequent identification, enumeration and measurement of individual body size (shell length for cymatid snails and carapace width for portunid crabs). The biofouling dry biomass on the nets was also estimated based on the difference between the weight of the pearl net sun-dried for $7 \mathrm{~d}$ and the ini- 
tial weight of the clean net. Finally, the scallops were placed in new pearl nets at their original densities with the number of animals readjusted in each net according to the method described above, and the culture systems were returned to the original depth. Every month, surplus animals extracted from each pearl net were distributed in extra replicates under the same conditions as those of the experimental juveniles in order to subsequently adjust the density in the case of high mortalities. The experiments lasted 6 mo for both species, between March and September 2011 for A. nucleus and between June and December of 2012 for $N$. nodosus.

Every 2 wk, 3 seawater samples (4 l) were collected using a Niskin bottle at the 3 culture depths. Seston concentration and organic content of each sample were determined following the methods of Strickland \& Parsons (1972). Salinity was measured using a refractometer (Brixco, precision $1 \mathrm{ppt}$ ), and temperature was registered from glass maximum-minimum thermometers (Sper Scientific, precision $1^{\circ} \mathrm{C}$ ) maintained at each depth. Due to administrative problems in the project, it was not possible to take water samples between June and July of 2012.

The existence of statistical differences in the growth and survival of scallops between culture depth and frequency of net replacement was analyzed using a 2-way ANCOVA, with time as the covariate variable. The frequency of presence and size of predators, as well as the biofouling dry biomass, were compared between treatments and different periods of time using a factorial ANOVA. Physicalchemical parameters (i.e. temperature, salinity, ses- ton concentration and organic content) were compared between different culture depths and periods of time using a 2-way ANOVA. When differences among treatments and/or periods of time were detected, Bonferroni or Tukey multiple tests were performed to detect the specific intra-level differences. Before the analysis, data normality and homoscedasticity were confirmed in almost all cases, and transformations were applied when required. Thus, predator size data were log transformed, data for shell length in $N$. nodosus and biofouling dry biomass were ranked, and data for frequency of presence of predators were square-root transformed. Temperature data for A. nucleus culture did not comply with the normality and homoscedasticity requirements, so these data were analyzed using the Kruskal-Wallis test. Correlation analysis of the data (i.e. physicalchemical variables, monthly growth and survival rates of scallops, frequency of presence and size of predators, and biofouling dry biomass) was performed using Spearman's correlation. The Statgraphics Centurion XVII X64 software was used for all statistical analysis, with significance level of $\alpha=0.05$.

\section{RESULTS}

\subsection{Argopecten nucleus}

Survival of A. nucleus after 6 mo in suspended culture varied between 29 and $48 \%$ (Fig. 1A), with the highest decrease (41-68\%) registered in the first sampling, at 30 or $65 \mathrm{~d}$ culture time. Juveniles with
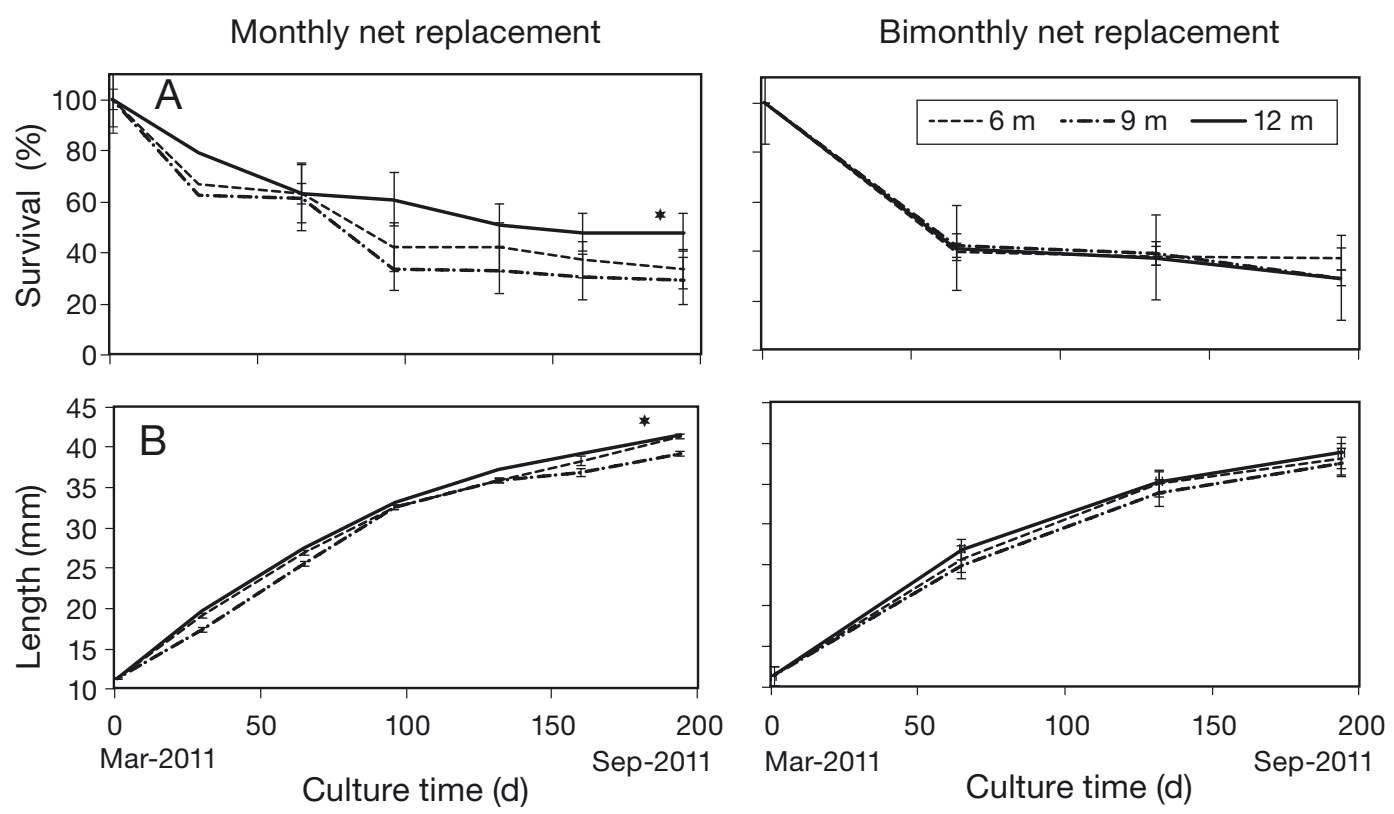

Bimonthly net replacement

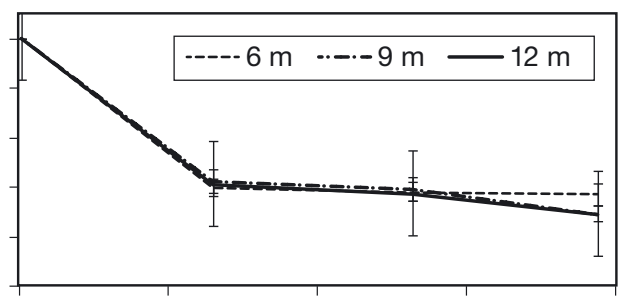

Fig. 1. Mean $\pm \mathrm{SE}(\mathrm{A})$ survival and (B) growth in shell length of Argopecten nucleus maintained at different conditions (i.e. culture depths and net replacement frequencies. ${ }^{*} p<0.05$ 
an initial shell length of $11.3 \mathrm{~mm}$ reached between 37.5 and $41.6 \mathrm{~mm}$ (Fig. 1B) at the end of the experiment, with growth rates between 0.14 and $0.16 \mathrm{~mm}$ $\mathrm{d}^{-1}$. Highest survival and growth rates were found in animals cultured at a depth of $12 \mathrm{~m}$ and where net replacement was monthly (Table 1). The water temperature between March and September of 2011 varied between 23 and $29^{\circ} \mathrm{C}$ (Fig. 2A), with the lowest values at a depth of $12 \mathrm{~m}$ in March and the highest values at 6 and $9 \mathrm{~m}$ in July and August $(K-\mathrm{W}=6.0, \mathrm{p}<$
0.0098). Salinity fluctuated between 34 and 37 ppt (Fig. 2B), with the highest values at depths of 9 and $12 \mathrm{~m}$ in March and the lowest values at $6 \mathrm{~m}$ in May (Table 2). Seston concentration fluctuated between 1.8 and $7.7 \mathrm{mg} \mathrm{l}^{-1}$ (Fig. 2C), being highest at depths of 9 and $12 \mathrm{~m}$ in April and June and lowest at $6 \mathrm{~m}$ from April to June (Table 2). Seston organic content oscillated between 17 and $82 \%$ (Fig. 2D), registering highest values at a depth of $12 \mathrm{~m}$ in May with lowest at $9 \mathrm{~m}$ from June to August (Table 2). Significant neg-

Table 1. ANCOVAs and ANOVAs of the survival and shell length of Argopecten nucleus and Nodipecten nodosus maintained at different suspended culture conditions (i.e. culture depths and net replacement frequencies)

\begin{tabular}{|c|c|c|c|c|c|c|}
\hline Variable & Source of variation & SS & df & Square means & $F$ & $\mathrm{p}$ \\
\hline \multirow[t]{4}{*}{ Survival } & Covariable: Culture time & 42762.10 & 1 & 42762.10 & 169.71 & 0.0000 \\
\hline & A: Depth & 705.85 & 2 & 352.92 & 1.4 & 0.0216 \\
\hline & B: Net replacement & 243.38 & 1 & 243.38 & 0.97 & 0.0283 \\
\hline & $\mathrm{A} \times \mathrm{B}$ Interaction & 928.72 & 2 & 464.36 & 1.84 & 0.1642 \\
\hline \multirow[t]{4}{*}{ Shell length } & Covariable: Culture time & 306162.00 & 1 & 306162.00 & 20117.48 & 0.0000 \\
\hline & A: Depth & 605.75 & 2 & 302.87 & 19.9 & 0.0000 \\
\hline & B: Net replacement & 1703.96 & 1 & 1703.96 & 111.97 & 0.0000 \\
\hline & $\mathrm{A} \times \mathrm{B}$ Interaction & 57.03 & 2 & 28.51 & 1.87 & 0.1537 \\
\hline \multirow[t]{7}{*}{ Cymatid frequency } & A: Culture time & 0.81 & 2 & 0.40 & 1.86 & 0.1698 \\
\hline & B: Depth & 0.40 & 2 & 0.20 & 0.93 & 0.4041 \\
\hline & C: Net replacement & 0.80 & 1 & 0.80 & 3.7 & 0.0624 \\
\hline & $\mathrm{A} \times \mathrm{B}$ Interaction & 0.96 & 4 & 0.24 & 1.11 & 0.3685 \\
\hline & $\mathrm{A} \times \mathrm{C}$ Interaction & 0.16 & 2 & 0.08 & 0.37 & 0.6967 \\
\hline & $\mathrm{B} \times \mathrm{C}$ Interaction & 0.17 & 2 & 0.09 & 0.39 & 0.6774 \\
\hline & $\mathrm{A} \times \mathrm{B} \times \mathrm{C}$ Interaction & 0.81 & 4 & 0.20 & 0.94 & 0.4535 \\
\hline \multirow[t]{7}{*}{ Cymatid size } & A: Culture time & 4.37 & 2 & 2.19 & 1.67 & 0.2024 \\
\hline & B: Depth & 2.77 & 2 & 1.38 & 1.06 & 0.358 \\
\hline & C: Net replacement & 2.94 & 1 & 2.94 & 2.24 & 0.1428 \\
\hline & $\mathrm{A} \times \mathrm{B}$ Interaction & 9.92 & 4 & 2.48 & 1.9 & 0.1325 \\
\hline & $\mathrm{A} \times \mathrm{C}$ Interaction & 1.18 & 2 & 0.59 & 0.45 & 0.641 \\
\hline & $\mathrm{B} \times \mathrm{C}$ Interaction & 3.24 & 2 & 1.62 & 1.24 & 0.3024 \\
\hline & $\mathrm{A} \times \mathrm{B} \times \mathrm{C}$ Interaction & 4.21 & 4 & 1.05 & 0.8 & 0.5304 \\
\hline \multirow[t]{7}{*}{ Portunid frequency } & A: Culture time & 2.90 & 2 & 1.45 & 3.31 & 0.0478 \\
\hline & B: Depth & 1.85 & 2 & 0.92 & 2.11 & 0.1365 \\
\hline & C: Net replacement & 1.56 & 1 & 1.56 & 3.56 & 0.0673 \\
\hline & A $\times$ B Interaction & 3.16 & 4 & 0.79 & 1.8 & 0.1503 \\
\hline & $\mathrm{A} \times \mathrm{C}$ Interaction & 0.83 & 2 & 0.41 & 0.94 & 0.399 \\
\hline & $\mathrm{B} \times \mathrm{C}$ Interaction & 0.24 & 2 & 0.12 & 0.27 & 0.7637 \\
\hline & $\mathrm{A} \times \mathrm{B} \times \mathrm{C}$ Interaction & 0.75 & 4 & 0.19 & 0.43 & 0.7894 \\
\hline \multirow[t]{7}{*}{ Portunid size } & A: Culture time & 597.28 & 2 & 298.64 & 3.62 & 0.0368 \\
\hline & B: Depth & 240.25 & 2 & 120.13 & 1.46 & 0.2462 \\
\hline & C: Net replacement & 570.51 & 1 & 570.51 & 6.92 & 0.0125 \\
\hline & $\mathrm{A} \times \mathrm{B}$ Interaction & 332.37 & 4 & 83.09 & 1.01 & 0.4161 \\
\hline & $\mathrm{A} \times \mathrm{C}$ Interaction & 164.88 & 2 & 82.44 & 1 & 0.3777 \\
\hline & $\mathrm{B} \times \mathrm{C}$ Interaction & 171.23 & 2 & 85.61 & 1.04 & 0.3642 \\
\hline & $\mathrm{A} \times \mathrm{B} \times \mathrm{C}$ Interaction & 161.87 & 4 & 40.47 & 0.49 & 0.7423 \\
\hline \multirow[t]{7}{*}{ Fouling } & A: Culture time & 3198.04 & 2 & 1599.02 & 17.43 & 0.0000 \\
\hline & B: Depth & 6486.26 & 2 & 3243.13 & 35.34 & 0.0000 \\
\hline & C: Net replacement & 9680.17 & 1 & 9680.17 & 105.5 & 0.0000 \\
\hline & $\mathrm{A} \times \mathrm{B}$ Interaction & 21776.00 & 4 & 5443.99 & 59.33 & 0.0000 \\
\hline & $\mathrm{A} \times \mathrm{C}$ Interaction & 80.11 & 2 & 40.06 & 0.44 & 0.6497 \\
\hline & $\mathrm{B} \times \mathrm{C}$ Interaction & 1440.78 & 2 & 720.39 & 7.85 & 0.0015 \\
\hline & $\mathrm{A} \times \mathrm{B} \times \mathrm{C}$ Interaction & 458.11 & 4 & 114.53 & 1.25 & 0.3082 \\
\hline
\end{tabular}



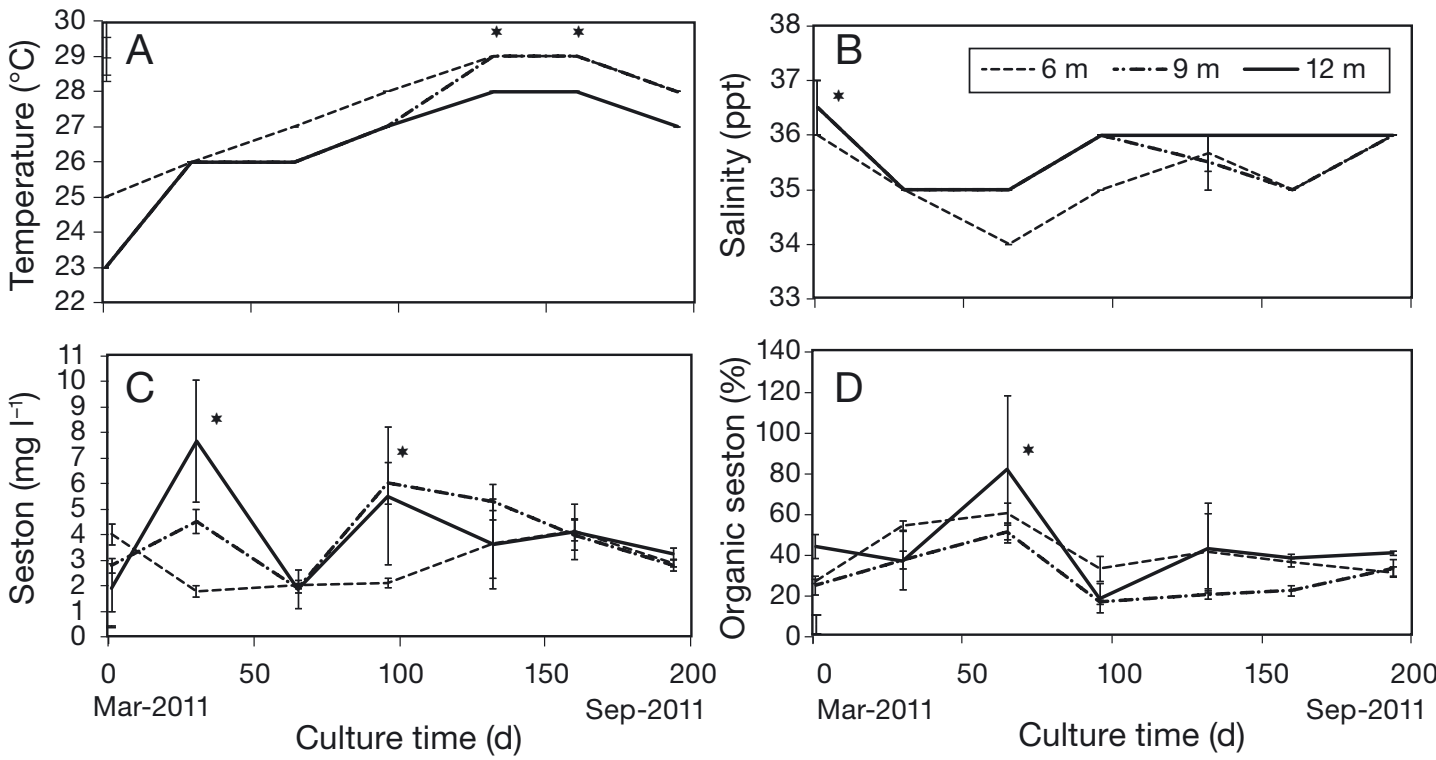

Fig. 2. Mean \pm SE (A) temperature, (B) salinity, (C) seston concentration and (D) seston organic content in Taganga Bay during the experimental culture of A. nucleus. ${ }^{*} \mathrm{p}<0.05$

Table 2. ANOVAs of the physicochemical parameters of Taganga Bay (Santa Marta, Colombia) at different depths and months at which Argopecten nucleus and Nodipecten nodosus were cultured

\begin{tabular}{|c|c|c|c|c|c|c|c|}
\hline Species & Variable & Source of variation & SS & $\mathrm{df}$ & Square means & $F$ & $\mathrm{p}$ \\
\hline \multirow[t]{9}{*}{ A. nucleus } & \multirow{3}{*}{ Salinity } & A: Depth & 2.78 & 2 & 1.39 & 20.55 & 0.0000 \\
\hline & & B: Culture time & 13.99 & 6 & 2.33 & 34.43 & 0.0000 \\
\hline & & $\mathrm{A} \times \mathrm{B}$ Interaction & 3.27 & 12 & 0.27 & 4.03 & 0.0008 \\
\hline & \multirow[t]{3}{*}{ Seston } & A: Depth & 12.50 & 2 & 6.25 & 3.02 & 0.0631 \\
\hline & & B: Culture time & 43.57 & 6 & 7.26 & 3.50 & 0.0089 \\
\hline & & $\mathrm{A} \times \mathrm{B}$ Interaction & 63.03 & 12 & 5.25 & 2.53 & 0.0178 \\
\hline & \multirow[t]{3}{*}{ Seston organic } & A: Depth & 1720.30 & 2 & 860.15 & 3.95 & 0.0293 \\
\hline & & B: Culture time & 7105.03 & 6 & 1184.17 & 5.44 & 0.0006 \\
\hline & & $\mathrm{A} \times \mathrm{B}$ Interaction & 1985.86 & 12 & 165.49 & 0.76 & 0.6844 \\
\hline \multirow[t]{12}{*}{ N. nodosus } & \multirow[t]{3}{*}{ Temperature } & A: Depth & 3.60 & 2 & 1.80 & 2.50 & 0.0000 \\
\hline & & B: Net replacement & 52.80 & 4 & 13.20 & 10.11 & 0.0000 \\
\hline & & $\mathrm{A} \times \mathrm{B}$ Interaction & 2.40 & 8 & 0.30 & 0.33 & 0.0000 \\
\hline & \multirow[t]{3}{*}{ Salinity } & A: Depth & 0.96 & 2 & 0.48 & 2.48 & 0.0000 \\
\hline & & B: Culture time & 13.00 & 4 & 3.25 & 16.71 & 0.0000 \\
\hline & & $\mathrm{A} \times \mathrm{B}$ Interaction & 1.06 & 8 & 0.13 & 0.68 & 0.0000 \\
\hline & \multirow[t]{3}{*}{ Seston } & A: Depth & 0.02 & 2 & 0.01 & 0.08 & 0.9206 \\
\hline & & B: Culture time & 0.13 & 4 & 0.03 & 0.34 & 0.8481 \\
\hline & & $\mathrm{A} \times \mathrm{B}$ Interaction & 0.95 & 8 & 0.12 & 1.28 & 0.2912 \\
\hline & \multirow[t]{3}{*}{ Seston organic } & A: Depth & 2026.17 & 2 & 1013.08 & 4.38 & 0.5215 \\
\hline & & B: Culture time & 495.90 & 4 & 123.98 & 0.54 & 0.7107 \\
\hline & & $\mathrm{A} \times \mathrm{B}$ Interaction & 1568.18 & 8 & 196.02 & 0.85 & 0.5701 \\
\hline
\end{tabular}

ative correlations were found between the monthly growth rates of $A$. nucleus and water temperature (Table 3).

The frequency of presence of cymatid snails in the pearl nets oscillated between 0 and 16 ind. $\mathrm{m}^{-2}$, their shell lengths fluctuated between 3 and $28 \mathrm{~mm}$ (Fig. 3A), and their growth rates ranged between 0 and $16 \mathrm{~mm} \mathrm{mo}^{-1}$. The frequency of presence of portunid crabs varied between 0 and 46 ind. $\mathrm{m}^{-2}$, while their carapace widths were between 4 and $42 \mathrm{~mm}$ (Fig. 3B), and their growth rates were between 0 and $24 \mathrm{~mm} \mathrm{mo}^{-1}$. Significantly higher frequency and size of portunids were registered in April and/or June than in August (Table 1). No statistical differences 
Table 3. Spearman correlation analysis between environmental parameters, the monthly growth rates and survival values of Argopecten nucleus and Nodipecten nodosus under different suspended culture conditions

\begin{tabular}{|c|c|c|c|c|c|c|c|c|c|c|c|c|}
\hline \multirow{3}{*}{ Parameter } & \multicolumn{6}{|c|}{ - A. nucleus } & \multirow{2}{*}{\multicolumn{6}{|c|}{$\begin{array}{l}\text { Growth rate } \\
\text { N. nodosus }\end{array}$}} \\
\hline & \multicolumn{3}{|c|}{ Growth rate } & \multicolumn{3}{|c|}{ Survival } & & & & & & \\
\hline & $\mathrm{r}$ & $\mathrm{n}$ & $\mathrm{p}$ & $\mathrm{r}$ & $\mathrm{n}$ & $\mathrm{p}$ & $\mathrm{r}$ & $\mathrm{n}$ & $\mathrm{p}$ & $\mathrm{r}$ & $\mathrm{n}$ & $\mathrm{p}$ \\
\hline Temp & -0.9281 & 27 & 0.0000 & 0.5547 & 27 & 0.0514 & 0.4956 & 23 & 0.0201 & -0.3013 & 24 & 0.1484 \\
\hline Salinity & 0.1031 & 27 & 0.5990 & -0.2234 & 27 & 0.2546 & -0.1933 & 23 & 0.3647 & 0.0196 & 24 & 0.9252 \\
\hline Seston & -0.2326 & 27 & 0.2356 & -0.0037 & 27 & 0.9851 & -0.3323 & 23 & 0.1191 & -0.0431 & 24 & 0.8363 \\
\hline Organic seston & 0.1856 & 27 & 0.3440 & 0.0418 & 27 & 0.8311 & -0.1286 & 23 & 0.5465 & 0.0274 & 24 & 0.8954 \\
\hline Cymatid frequency & -0.1244 & 27 & 0.5258 & -0.2710 & 27 & 0.1670 & 0.1901 & 23 & 0.3726 & -0.1251 & 24 & 0.5486 \\
\hline Portunid frequency & 0.2670 & 27 & 0.1734 & -0.2121 & 27 & 0.2794 & 0.0015 & 23 & 0.9943 & -0.1698 & 24 & 0.4154 \\
\hline Cymatid size & 0.1909 & 18 & 0.4312 & -0.3849 & 18 & 0.1125 & 0.6571 & 6 & 0.1417 & -0.3714 & 6 & 0.4062 \\
\hline Portunid size & 0.4898 & 20 & 0.0327 & -0.2521 & 20 & 0.2719 & 0.0214 & 15 & 0.9361 & 0.0321 & 15 & 0.9043 \\
\hline Cymatid growth rate & 0.2819 & 17 & 0.2596 & -0.4779 & 17 & 0.0559 & 0.3241 & 17 & 0.1949 & -0.2028 & 18 & 0.4030 \\
\hline Portunid growth rate & 0.7606 & 18 & 0.0017 & -0.3127 & 18 & 0.1973 & 0.2022 & 17 & 0.4186 & -0.2909 & 18 & 0.2303 \\
\hline Fouling & 0.1043 & 18 & 0.6670 & -0.3514 & 18 & 0.1474 & 0.2598 & 17 & 0.2987 & -0.0320 & 18 & 0.8951 \\
\hline
\end{tabular}

were found for the frequency of presence and size of cymatid predators found in the pearl nets at different culture depths or net replacement frequencies (Table 1). The biofouling dry biomass fluctuated between 215 and $1143 \mathrm{~g} \mathrm{~m}^{-2}$ (Fig. 3C), with the higher values found under a bimonthly net replacement scheme, in the month of August, and in pearl nets kept at a depth of $6 \mathrm{~m}$, except in April when higher biofouling values were verified at $12 \mathrm{~m}$ (Table 1). Significant positive correlations were found between the size of portunid crabs, the crab growth rate and the monthly growth of $A$. nucleus (Table 3 ).

\subsection{Nodipecten nodosus}

Survival of $N$. nodosus juveniles after 6 mo in suspended culture fluctuated between 0 and $44 \%$ (Fig. 4A), with marked declines (35-54\%) registered in the first sampling at 30 or $65 \mathrm{~d}$ culture time. Survival values were significantly higher in animals maintained at a depth of $12 \mathrm{~m}$ and under a bimonthly net replacement scheme (Table 4). Juveniles with an initial shell length of $8.5 \mathrm{~mm}$ reached between 45.6 and $49.6 \mathrm{~mm}$ (Fig. 4B), exhibiting monthly growth rates from 0.21 to $0.24 \mathrm{~mm} \mathrm{~d}^{-1}$. The greatest growth was observed in animals cultured at a depth of $6 \mathrm{~m}$ and with bimonthly net replacement (Table 4). From August to December of 2012, the water temperature oscillated between 25 and $29^{\circ} \mathrm{C}$ (Fig. 5A), with the lowest values at depths of 9 and $12 \mathrm{~m}$ in December and the highest values at $6 \mathrm{~m}$ in November (Table 2). Salinity fluctuated between 35 and 38 ppt (Fig. 5B), being significantly higher in December and lower in September at a depth of 6 and $9 \mathrm{~m}$ (Table 2). Seston concentration varied between 1.8 and $4.3 \mathrm{mg} \mathrm{l}^{-1}$ (Fig. 5C), with no significant differences found in different months and culture depths (Table 2). Seston organic content fluctuated between 31 and $65 \%$ (Fig. 5D), with no significant differences found between different months (Table 2), but with values significantly higher at a depth of $12 \mathrm{~m}$ (Table 2). A significant, positive correlation was found between the growth rate of $N$. nodosus and water temperature (Table 3 ).

The frequency of presence of cymatid snails in the pearl nets fluctuated between 0 and 8 ind. $\mathrm{m}^{-2}$, while their size varied between 8 and $40 \mathrm{~mm}$ (Fig. 6A), and their growth rates were between 0 and $40 \mathrm{~mm} \mathrm{mo}^{-1}$. Similarly, the frequency of presence of portunid crabs oscillated between 0 and 16 ind. $\mathrm{m}^{-2}$, and their carapace width presented values between 7 and $25 \mathrm{~mm} \mathrm{mo}^{-1}$ (Fig. 6B), and their growth rates were between 0 and $15 \mathrm{~mm} \mathrm{mo}^{-1}$. No significant differences were found in the frequency of presence or growth rate of predators between different months, culture depths or different net replacement frequencies (Table 4) during the experiment. Biofouling dry biomass fluctuated between 73.7 and $1083.3 \mathrm{~g} \mathrm{~m}^{-2}$ (Fig. 6C). Significantly higher values were registered under bimonthly net replacement, especially in August and at 6 or $9 \mathrm{~m}$ of depth (Table 4). There was no significant correlation between predators or biofouling variables and the growth or survival of N. nodosus (Table 3 ).

\section{DISCUSSION}

The present study demonstrates how survival and growth of the 2 Caribbean pectinid species studied 

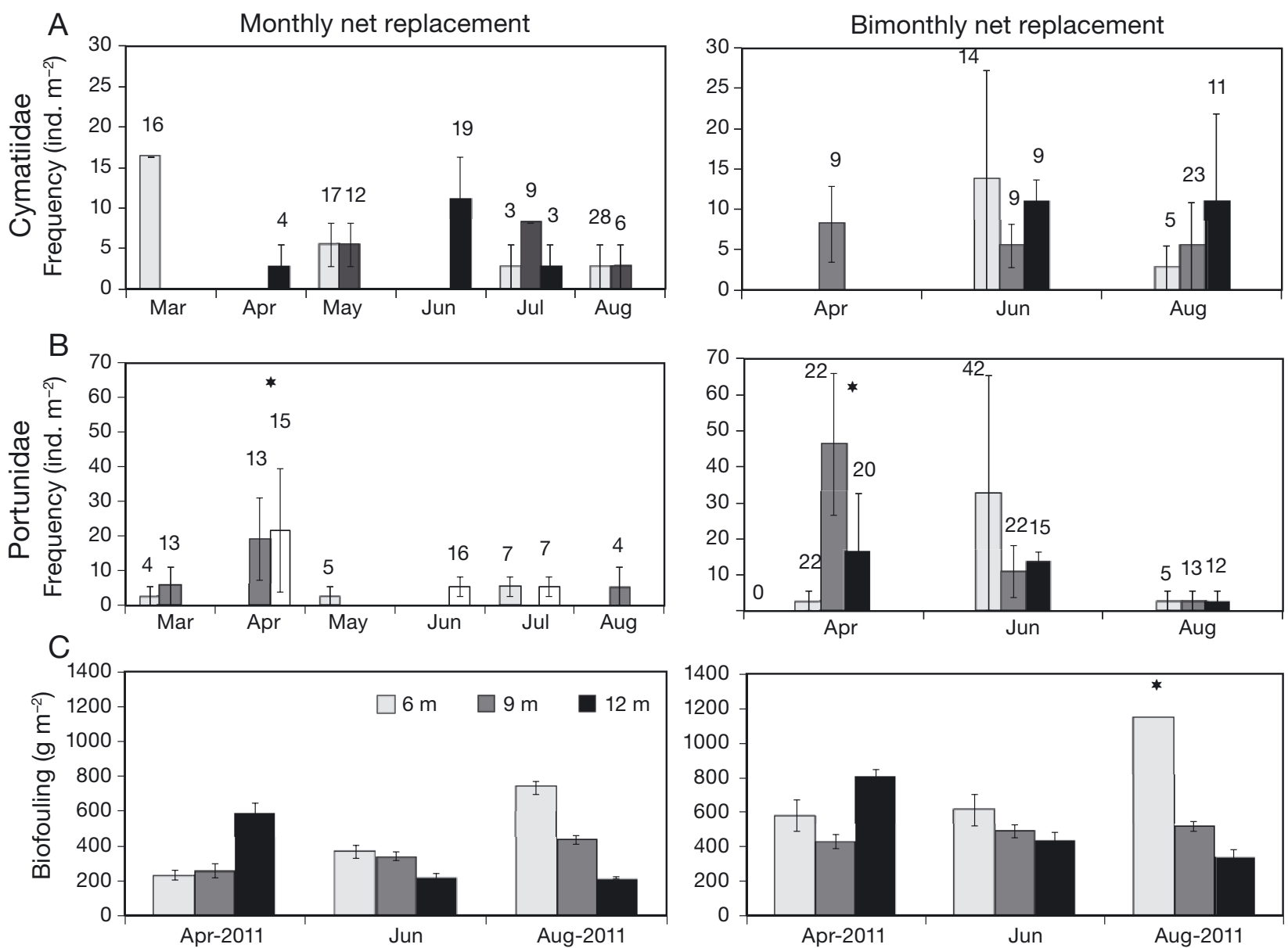

Fig. 3. Mean \pm SE frequency of presence and size of the predators (A) Cymatiidae and (B) Portunidae inside the pearl nets with Argopecten nucleus and (C) biofouling dry biomass in the nets under different conditions (i.e. culture depths and net replacement frequencies). Numbers above bars represent the predator size means in mm (shell length for cymatid snails and carapace width for portunid crabs). ${ }^{*} \mathrm{p}<0.05$
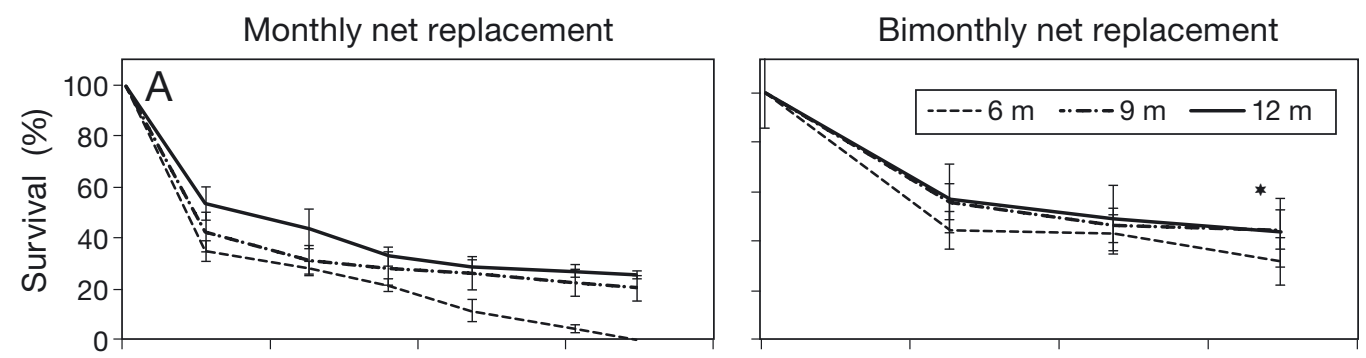

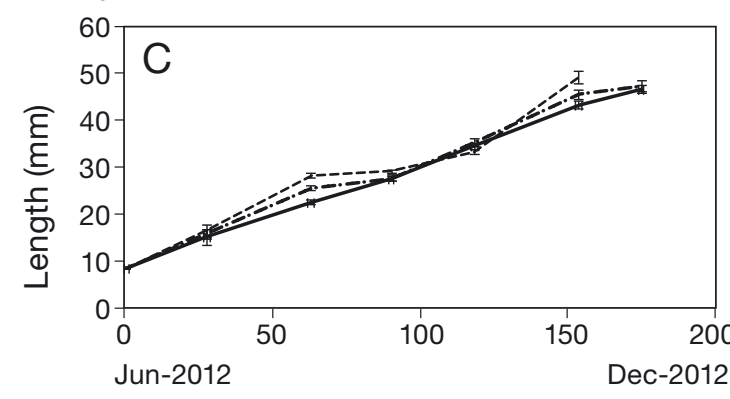

Culture time $(d)$

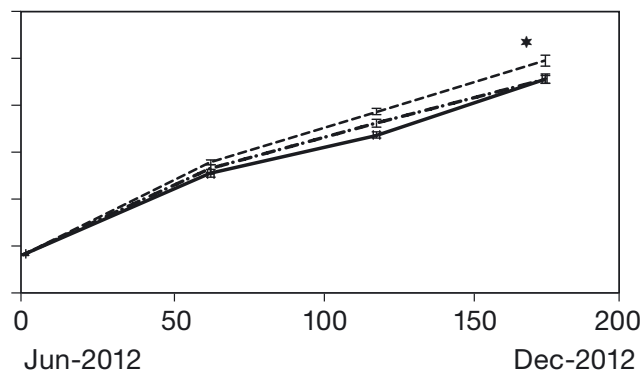

Culture time (d)
Fig. 4. Mean \pm SE (A) survival and (B) growth in shell length of Nodipecten nodosus maintained at different conditions (i.e. culture depths and net replacement frequencies). ${ }^{*} \mathrm{p}<0.05$ 
Table 4. ANCOVAs and ANOVAs of the survival and shell length of Nodipecten nodosus maintained at different suspended culture conditions (i.e. culture depths and net replacement frequencies)

\begin{tabular}{|c|c|c|c|c|c|c|}
\hline Variable & Source of variation & SS & $\mathrm{df}$ & Square means & $F$ & $\mathrm{p}$ \\
\hline \multirow[t]{4}{*}{ Survival } & Covariable: Culture time & 47523.10 & 1 & 47523.10 & 172.36 & 0.0000 \\
\hline & A: Depth & 2232.20 & 2 & 1116.10 & 4.05 & 0.0207 \\
\hline & B: Net replacement & 11450.90 & 1 & 11450.90 & 41.53 & 0.0000 \\
\hline & $\mathrm{A} \times \mathrm{B}$ Interaction & 256.60 & 2 & 128.30 & 0.47 & 0.6294 \\
\hline \multirow[t]{4}{*}{ Shell length } & Covariable: Culture time & 374641000.00 & 1 & 374641000.00 & 5467.62 & 0.0000 \\
\hline & A: Depth & 3172850.00 & 2 & 1586420.00 & 23.15 & 0.0000 \\
\hline & B: Net replacement & 827432.00 & 1 & 827432.00 & 12.08 & 0.0005 \\
\hline & $\mathrm{A} \times \mathrm{B}$ Interaction & 405746.00 & 2 & 202873.00 & 2.96 & 0.0520 \\
\hline \multirow[t]{7}{*}{ Cymatid frequency } & A: Culture time & 0.28 & 2 & 0.14 & 1.78 & 0.1835 \\
\hline & B: Depth & 0.07 & 2 & 0.04 & 0.44 & 0.6447 \\
\hline & C: Net replacement & 0.14 & 1 & 0.14 & 1.78 & 0.1908 \\
\hline & $\mathrm{A} \times \mathrm{B}$ Interaction & 0.06 & 2 & 0.03 & 0.24 & 0.7885 \\
\hline & $\mathrm{A} \times \mathrm{C}$ Interaction & 0.36 & 4 & 0.09 & 1.11 & 0.3664 \\
\hline & $\mathrm{B} \times \mathrm{C}$ Interaction & 0.07 & 2 & 0.04 & 0.44 & 0.6447 \\
\hline & $\mathrm{A} \times \mathrm{B} \times \mathrm{C}$ Interaction & 0.07 & 2 & 0.04 & 0.44 & 0.6447 \\
\hline \multirow[t]{7}{*}{ Cymatid size } & A: Culture time & 241.25 & 2 & 120.63 & 1.75 & 0.1875 \\
\hline & B: Depth & 102.98 & 2 & 51.49 & 0.75 & 0.4801 \\
\hline & C: Net replacement & 63.74 & 1 & 63.74 & 0.93 & 0.3421 \\
\hline & $\mathrm{A} \times \mathrm{B}$ Interaction & 96.04 & 4 & 24.01 & 0.35 & 0.8428 \\
\hline & $\mathrm{A} \times \mathrm{C}$ Interaction & 70.58 & 2 & 35.29 & 0.51 & 0.6028 \\
\hline & $\mathrm{B} \times \mathrm{C}$ Interaction & 82.24 & 2 & 41.12 & 0.6 & 0.5552 \\
\hline & $\mathrm{A} \times \mathrm{B} \times \mathrm{C}$ Interaction & 466.71 & 4 & 116.68 & 1.7 & 0.1721 \\
\hline \multirow[t]{7}{*}{ Portunid frequency } & A: Culture time & 0.48 & 2 & 0.24 & 0.37 & 0.6924 \\
\hline & B: Depth & 2.48 & 2 & 1.24 & 1.91 & 0.1622 \\
\hline & C: Net replacement & 1.19 & 1 & 1.19 & 1.83 & 0.1847 \\
\hline & $\mathrm{A} \times \mathrm{B}$ Interaction & 0.19 & 2 & 0.09 & 0.48 & 0.6233 \\
\hline & $\mathrm{A} \times \mathrm{C}$ Interaction & 4.74 & 4 & 1.19 & 1.83 & 0.1447 \\
\hline & $\mathrm{B} \times \mathrm{C}$ Interaction & 1.37 & 2 & 0.69 & 1.06 & 0.358 \\
\hline & $\mathrm{A} \times \mathrm{B} \times \mathrm{C}$ Interaction & 0.26 & 2 & 0.13 & 0.2 & 0.8196 \\
\hline \multirow[t]{7}{*}{ Portunid size } & A: Culture time & 99.81 & 2 & 49.90 & 0.87 & 0.4256 \\
\hline & B: Depth & 457.25 & 2 & 228.62 & 4.01 & 0.0568 \\
\hline & C: Net replacement & 346.39 & 1 & 346.39 & 6.07 & 0.0586 \\
\hline & $\mathrm{A} \times \mathrm{B}$ Interaction & 723.30 & 4 & 180.82 & 3.17 & 0.0549 \\
\hline & $\mathrm{A} \times \mathrm{C}$ Interaction & 90.39 & 2 & 45.19 & 0.79 & 0.4606 \\
\hline & $\mathrm{B} \times \mathrm{C}$ Interaction & 114.75 & 2 & 57.37 & 1.01 & 0.3758 \\
\hline & $\mathrm{A} \times \mathrm{B} \times \mathrm{C}$ Interaction & 389.16 & 4 & 97.29 & 1.71 & 0.1702 \\
\hline \multirow[t]{7}{*}{ Fouling } & A: Culture time & 1838.53 & 2 & 919.26 & 20.95 & 0.0000 \\
\hline & B: Depth & 4139.53 & 2 & 2069.76 & 47.16 & 0.0000 \\
\hline & C: Net replacement & 20126.00 & 1 & 20126.00 & 458.6 & 0.0000 \\
\hline & $\mathrm{A} \times \mathrm{B}$ Interaction & 7768.61 & 4 & 1942.15 & 44.25 & 0.0562 \\
\hline & $\mathrm{A} \times \mathrm{C}$ Interaction & 1025.53 & 2 & 512.76 & 11.68 & 0.0001 \\
\hline & $\mathrm{B} \times \mathrm{C}$ Interaction & 2861.08 & 2 & 1430.54 & 32.6 & 0.0698 \\
\hline & $\mathrm{A} \times \mathrm{B} \times \mathrm{C}$ Interaction & 7970.39 & 4 & 1992.60 & 45.4 & 0.0745 \\
\hline
\end{tabular}

are affected by culture depth and net replacement frequency, in addition to environmental variables such as water temperature, biofouling biomass and the size of portunid predators. These results facilitate a better understanding of the complex dynamics between environmental and operational variables inherent to scallop aquaculture in suspended systems and productive traits, which can support better management practices to improve productivity.

\subsection{Effect of depth}

The high survival of Argopecten nucleus and Nodipecten nodosus cultured at the greatest depth tested $(12 \mathrm{~m})$, as well as the highest growth of $A$. nucleus under such conditions, are similar to results previously reported for the survival of $N$. nodosus (Lodeiros et al. 1998), the growth and survival of Euvola ziczac (Lodeiros \& Himmelman 2000), and the 

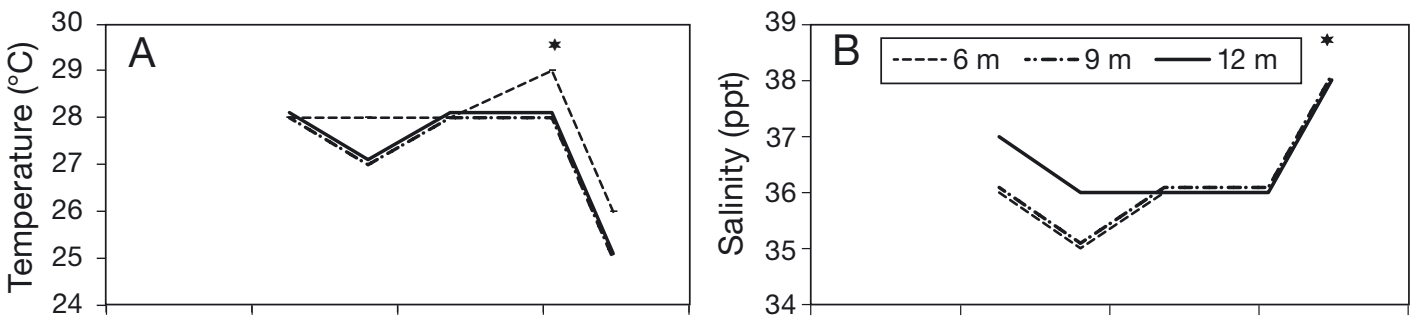

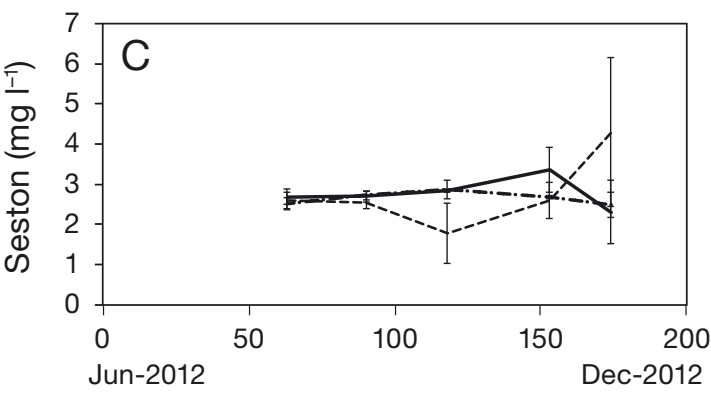

Culture time (d)

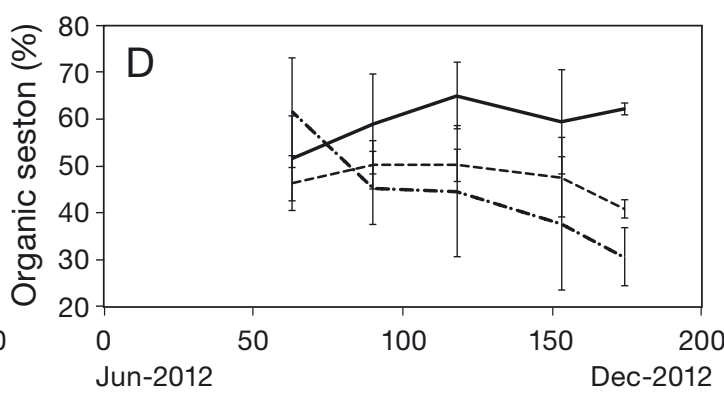

Culture time (d)
Fig. 5. Mean $\pm \mathrm{SE}(\mathrm{A})$ temperature, (B) salinity, (C) seston concentration and (D) seston organic content in Taganga Bay during the experimental culture of Nodipecten nodosus (August to December of 2012). ${ }^{*} \mathrm{p}<0.05$
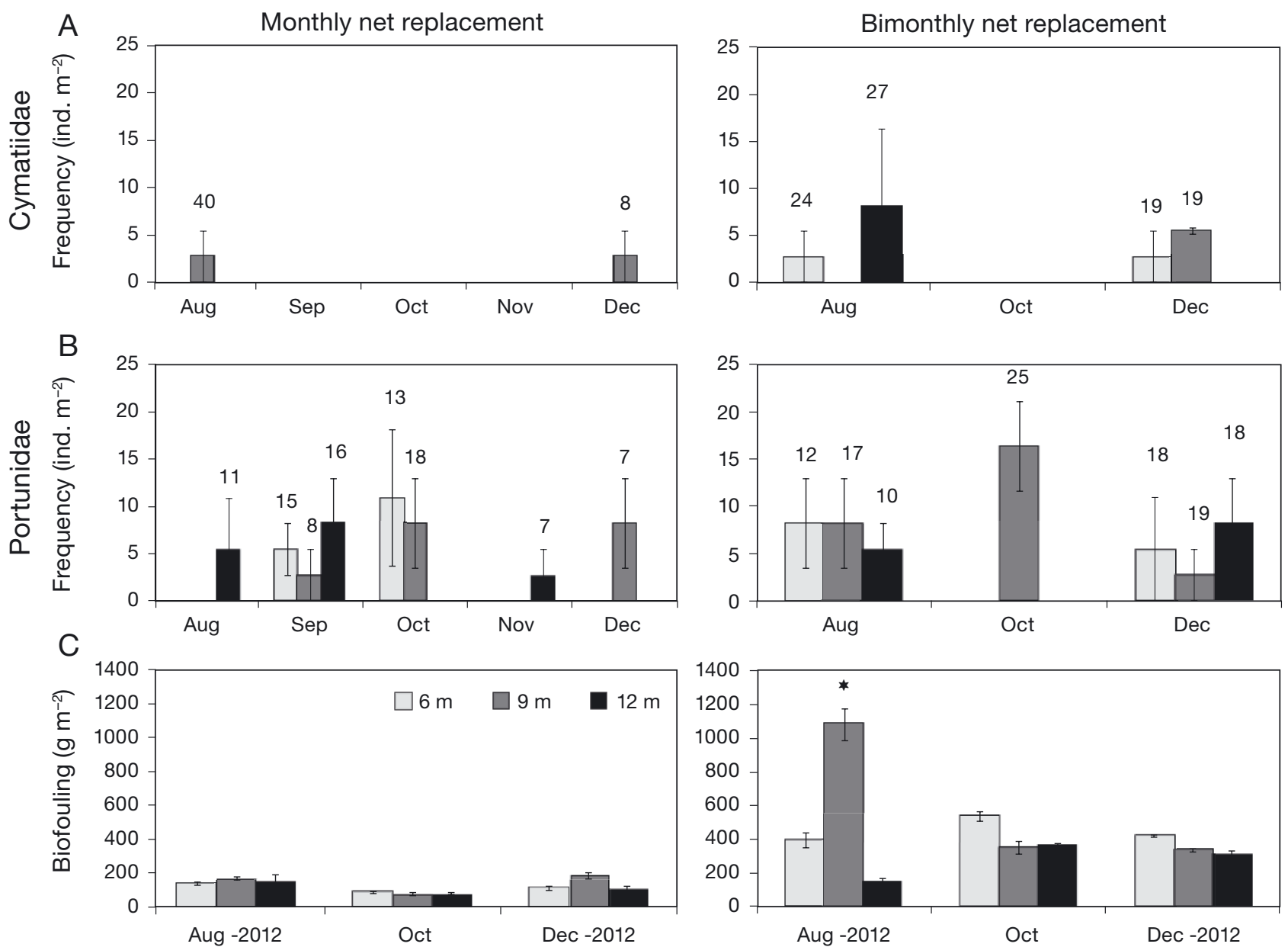

Fig. 6. Mean \pm SE frequency of presence and size of the predators (A) Cymatiidae and (B) Portunidae inside the pearl nets with Nodipecten nodosus and (C) biofouling dry biomass in the nets under different conditions (i.e. culture depths and net replacement frequencies). Numbers above bars represent the predator size means in mm (shell length for cymatid snails and carapace width for portunid crabs). ${ }^{*} \mathrm{p}<0.05$ 
growth of Aequipecten opercularis (Román et al. 1999) and Pecten maximus (Román et al. 2003). The lower temperatures as well as the lower values of biofouling dry biomass found in the pearl nets maintained at greater depths in most of the months suggest that these factors promoted survival in both pectinid species studied and the growth in A. nucleus. High temperatures $\left(28^{\circ} \mathrm{C}\right)$ can cause a decrease in food intake and an increase in metabolic demands, resulting in less energy available for growth and reproduction of these 2 species (Velasco 2006). Similarly, the presence of a larger biofouling biomass in the pearl nets maintained in shallow waters most of the months probably exerted additional stress in the scallops, thus increasing their susceptibility to death. Some of the main causes of stress on scallops related to the presence of biofouling are (1) toxic nitrogenous waste products released to the water, (2) competition for resources such as food, oxygen and space, and (3) energetic costs related to repair of shell damage caused by shell-boring organisms (Lesser et al. 1992, LeBlanc et al. 2002, Fitridge et al. 2012). In contrast, the highest growth of $N$. nodosus cultured at $6 \mathrm{~m}$ suggests that this species had large energetic reserves to support its growth and/or that it had low energetic demands for shell reparation under high temperature and biofouling abundance conditions. It has been shown that $N$. nodosus is capable of storing, transferring and using nutrients from the muscle and digestive gland to support somatic and gonadic growth, respectively (Lodeiros et al. 2001), especially under suboptimal conditions (Velasco \& Barros 2008). The suspension of the culture systems at greater depths, especially in August, was able to decrease the settlement of larval stages of biofouling species in the nets, thus promoting a positive effect on the survival of the 2 pectinid species studied and on the growth of $A$. nuleus.

\subsection{Effect of net replacement frequency}

The higher values of survival and growth in individuals of $A$. nucleus cultured under a monthly net replacement scheme, in comparison to those under a bimonthly scheme, are similar to those found for $E$. ziczac (Lodeiros \& Himmelman 1996), Placopecten magellanicus (Claereboudt et al. 1994) and Pinctada margaritifera (Pit \& Southgate 2003) cultured in systems with monthly and bimonthly net cleaning. These results are related to the higher values of biofouling biomass size and frequency of portunid crabs found in the pearl nets with bimonthly replacement.
Indeed, crabs of larger size are able to predate on a greater number of cultured scallops, which has been previously reported for Carcinus maenas (KleinBreteler 1975). Additionally, the positive correlation found between the size of portunid crabs and growth of A. nucleus suggests that portunids of larger size consumed a greater number of small scallops within the culture systems, which exhibited slower growth, therefore indirectly selecting larger scallops with a faster growth rate. Similar results have been reported in oysters Crassostrea virginica predated by crabs Callinectes sapidus (Eggleston 1990). It seems likely that a monthly net replacement contributes towards minimizing the settlement of larval stages of biofouling species in the nets as well as towards hindering the growth of portunid crabs, thus preventing them from reaching a critical body size within the pearl nets. These 2 aspects should explain the higher survival and growth of $A$. nucleus under a monthly net replacement scheme.

The high values of survival and growth observed in individuals of $N$. nodosus cultured under a bimonthly net replacement scheme suggest this species has low sensitivity to the deleterious effects of biofouling but high sensitivity to handling during net replacement. A lack of a significant relationship between the amount of biofouling and survival and growth has been previously documented for this species (Rupp 2007, Carraro et al. 2012) and other bivalves like Mytilus galloprovincialis and Ostrea edulis (Perera et al. 1999). The greater biofouling resistance of $N$. nodosus than of A. nucleus could be related to its higher shell thickness ( $1.5 \mathrm{~mm}$ vs. $1 \mathrm{~mm}$ in adults, respectively). Apparently, in $N$. nodosus, a monthly net replacement negatively affects survival and growth, which might be related to the stress inflicted by handling and manipulating the animals more frequently.

Higher mortality of $A$. nucleus and $N$. nodosus during the first period of experimental culture, immediately after seeding the scallops in the pearl nets (54 and $44 \%$ on average for $A$. nucleus and $N$. nodosus, respectively), suggest that the exposure to air, handling and manipulation during the detachment of juveniles from the artificial collectors, grading and seeding represent important stress factors that ultimately increase mortality rates. Usually these activities are performed for long periods of time (4 to $6 \mathrm{~h}$ ) in the beach at high water temperatures $\left(28\right.$ to $32^{\circ} \mathrm{C}$ ) and in limited shade, where the scallops are placed in containers at high densities with small volumes of seawater (20 to 50 l) and low water renewal. To increase survival and growth in this species, it is highly recommended to reduce the duration of the 
detachment, grading and seeding activities, in addition to implementing a system with flow-through tanks containing larger volumes of seawater.

\subsection{Predation and biofouling}

The maximum frequencies of presence of cymatid and portunid predators found in the pearl nets with A. nucleus and $N$. nodosus in Bahía Taganga (16 cymatids $\mathrm{m}^{-2} \mathrm{mo}^{-1}$ and 24 portunids $\mathrm{m}^{-2} \mathrm{mo}^{-1}$ ) are similar to those reported for $A$. nucleus in the same geographical area (22 cymatids $\mathrm{m}^{-2} \mathrm{mo}^{-1}$ and 11 portunids $\mathrm{m}^{-2} \mathrm{mo}^{-1}$; Velasco et al. 2009) but lower than those found in the protected area Parque Natural Nacional Tayrona in other bivalve species like Pinna carnea (45 cymatids $\mathrm{m}^{-2} \mathrm{mo}^{-1}$ and 33 portunids $\mathrm{m}^{-2}$ $\mathrm{mo}^{-1}$; Velasco \& Borrero 2004), Pteria colymbus (41 cymatids $\mathrm{m}^{-2}$ and 6 portunids $\mathrm{m}^{-2} \mathrm{mo}^{-1}$; Velasco \& Borrero 1996) and Pinctada imbricata (33 cymatids $\mathrm{m}^{-2} \mathrm{mo}^{-1}$ and 55 portunids $\mathrm{m}^{-2} \mathrm{mo}^{-1}$; Velasco \& Barros 2010). These results suggest that scallops are less appetizing or more difficult to predate than other Caribbean marine bivalves. This could also be indicative of a higher abundance of predators of bivalves inside protected areas. The growth rates of cymatids and portunids found in this study (40 and $42 \mathrm{~mm}$ $\mathrm{mo}^{-1}$, respectively) are high in relation to those estimated under suspended culture conditions of $\mathrm{P}$. COlymbus (12 to $26 \mathrm{~mm} \mathrm{mo}^{-1}$, respectively; Velasco \& Borrero 1996) and P. imbricata (23 to $25 \mathrm{~mm} \mathrm{mo}^{-1}$, respectively; Velasco \& Barros 2010). These differences could be related to temporal and spatial variations in water physicochemical conditions, changes in the species composition of the predator groups or differences in the nutritive value of the scallops and pearl oysters.

A decrease in the biofouling biomass in most culture systems at greater depths has been reported in other studies (Claereboudt et al. 1994, Rupp 2007). This decrease has been associated with the reduction of the supply of food for the biofouling biota, mainly composed of filter feeders or phototrophic organisms. This pattern was maintained under stratified conditions, but it was lost when upwelling or strong wind events took place, such as those verified in April 2011 as well as in August to October 2012, respectively. The lower average rate of biofouling formation in the pearl nets suspended in Taganga found in the present study $\left(190 \mathrm{~g} \mathrm{~m}^{-2} \mathrm{mo}^{-1}\right)$, in comparison to those reported in Chile for Argopecten purpuratus $(620 \mathrm{~g}$ $\mathrm{m}^{-2} \mathrm{mo}^{-1}$, Uribe et al. 2001), Venezuela for E. ziczac (384 $\mathrm{g} \mathrm{m}^{-2} \mathrm{mo}^{-1}$, Lodeiros \& Himmelman 2000) and $P$. imbricata (963 $\mathrm{g} \mathrm{m}^{-2} \mathrm{mo}^{-1}$, Lodeiros \& García 2004) and Canada for P. magellanicus (1900 $\mathrm{g} \mathrm{m}^{-2} \mathrm{mo}^{-1}$; Claereboudt et al. 1994), indicate that Bahía Taganga might offer favorable conditions for local bivalves aquaculture, given the relatively low incidence levels of predators and biofouling in the culture systems. The impact of biofouling in tropical zones has been considered negligible in comparison to the high biofouling biomass reported in temperate regions (Dürr \& Watson 2010). However, the lower survival of both scallops studied as well as the biofouling biomass obtained in shallow waters do not support this hypothesis. Also, although the level of biofouling in this study is lower (1.8 to $7.7 \mathrm{mg} \mathrm{l}^{-1}$ ) than in temperate waters, the same trend is also true for the seston concentration (63.1 to $77.8 \mathrm{mg} \mathrm{l}^{-1}$; Grizzle \& Morin 1989). So, even a low level of competition or flow obstruction of biofouling organisms could affect the tropical scallop performances. Considering that biofouling on the culture nets is one of the problems facing both scallop species studied, the use of cylindrical nets might be worthwhile as these may well have a lower surface area:volume ratio than pyramidal nets.

\section{CONCLUSIONS}

In summary, the suspension of culture systems at greater depths $(12 \mathrm{~m})$ is a suitable practice for reducing the settlement of larval stages of biofouling species and protecting the scallops from high temperatures, increasing survival in $N$. nodosus and $A$. nucleus as well as promoting growth in A. nucleus. A higher frequency of net replacement (i.e. monthly) reduces biofouling formation, thus increasing survival and growth in A. nucleus but not in $N$. nodosus, which seems to be affected to a greater degree by more frequent manipulation. However, considering that the low survival values obtained in this study were not mainly due to the environmental factors studied (i.e. predators, biofouling and physicochemical parameters) but instead due to the high mortality of juveniles at the beginning of the culture, it is recommended to carry out additional research to optimize the practices related to the operations of seed detachment from the artificial collectors, grading and seeding.

Acknowledgements. The authors would like to thank Walter Barbosa, the staff of the Laboratorio de Moluscos y Microalgas of the Universidad del Magdalena and the Asociación de Pescadores y Ostioneros de Taganga (ASPOTAG) for their help during the experiments. This study was supported 
by the Japan-Chile Partnership Programme (JCPP), Acción Social (ACCI) and Universidad del Magdalena Grant 2012, Universidad del Magdalena Grant Res. 0232-2017, 03392018 and 0025-2019 and COLCIENCIAS Grant N ${ }^{\circ} 1117-$ 808-64003 2019.

\section{LITERATURE CITED}

Acosta V, Freites L, Lodeiros C (2000) Densidad, crecimiento y supervivencia de juveniles de Lyropecten (Nodipecten) nodosus (Pteroida: Pectinidae) en cultivo suspendido en el golfo de Cariaco, Venezuela. Rev Biol Trop 48:799-806

Adams CM, Shumway SE, Whitlatch RB, Getchis T (2011) Biofouling in marine molluscan shellfish aquaculture: a survey assessing the business and economic implications of mitigation. J World Aquacult Soc 42:242-252

Barros J, Velasco LA, Winkler FM (2018) Heritability, genetic correlations and genotype by environment interactions in productive traits of the Caribbean scallop, Argopecten nucleus (Mollusca: Bivalvia). Aquaculture 488:39-48

Carraro JL, Rupp GS, Mothes B, Lerner C, Würdig NL (2012) Characterization of the fouling community of macroinvertebrates on the scallop Nodipecten nodosus (Mollusca, Pectinidae) farmed in Santa Catarina, Brazil. Cienc Mar 38:577-588

Ciocco NF, Orensanz JM (2001) Depredación. In: MaedaMartinez A (ed) Los moluscos pectinidos de Iberoamerica: ciencia y acuicultura. LIMUSA, Mexico City, p 267-284

Claereboudt MR, Bureau D, Coté J, Himmelman JH (1994) Fouling development and its effect on the growth of juvenile giant scallops (Placopecten magellanicus) in suspended culture. Aquaculture 121:327-342

Cortés-Useche C, Gomez-León J, Santos-Acevedo M (2011) Erizos de mar como control biológico del 'fouling' en un cultivo de Nodipecten nodosus en el área de Santa Marta, Caribe colombiano. Bol Investig Mar Costeras 40:233-247

Díaz JM, Puyana M (1994) Moluscos del Caribe Colombiano, un catálogo ilustrado. Colciencias, Fundación Natura y Universidad del Magdalena, Bogotá

Dürr S, Watson DI (2010) Biofouling and anti-fouling in aquaculture. In: Dürr S, Thomason JC (eds) Biofouling. Wiley-Blackwell, Singapore, p 267-287

Eggleston DB (1990) Functional responses of blue crabs Callinectes sapidus Rathbun feeding on juvenile oysters Crassostrea virginica (Gmelin): effects of predator sex and size, and prey size. J Exp Mar Biol Ecol 143:73-90

* Fitridge I, Dempster T, Guenther J, de Nys R (2012) The impact and control of biofouling in marine aquaculture: a review. Biofouling 28:649-669

Freedman K, Bell JD (1996) Effects of different substrata and protective mesh bags on collection of spat of the pearl oysters, Pinctada margaritifera (Linnaeus, 1758) and Pinctada maculata (Gould, 1850). J Shellfish Res 15:535-541

Freites L, Núñez M (2001) Cultivo suspendido de Lyropecten (Nodipecten) nodosus (L., 1758) mediante los métodos de bolsa y aurícula 'ear hanging'. Bol Inst Oceanogr 4:21-29

Freites L, Hilmmelman J, Lodeiros C (2000) Impact of predation by gastropods and crabs recruiting onto culture enclosures on the survival of the scallop Euvola ziczac (L.) in suspended culture. J Exp Mar Biol Ecol 244: 297-303
Gómez-León J, Acosta E, Castellanos C, Santos-Acevedo M (2010) Cultivo de Pectínidos en el Caribe colombiano. Proyecto. Optimización de la producción de postlarvas del ostión $N$. nodosus y la conchuela $A$. nucleus en el Caribe colombiano código 2105-09-17982. Serie de Publicaciones Generales No. 40, INVEMAR, Santa Marta

*Gizzle RE, Morin PJ (1989) Effect of tidal currents, seston, and bottom sediments on growth of Mercenaria mercenaria: results of a field experiment. Mar Biol 102:85-93

K Klein-Breteler WCM (1975) Food consumption, growth and energy metabolism of juvenile shore crabs, Carcinus maenas. Neth J Sea Res 9:255-272

LeBlanc A, Landry T, Miron G (2002) Fouling organisms in a mussel cultivated bay: their effect on nutrient uptake and release. Can Tech Rep Fish Aquat Sci 2431

* Lesser MP, Shumway SE, Cuccia T, Smith J (1992) Impact of fouling organisms on mussel rope culture: interspecific competition for food among suspension-feeding invertebrates. J Exp Mar Biol Ecol 165:91-102

* Lodeiros C, García N (2004) The use of sea urchins to control fouling during suspended culture of bivalves. Aquaculture 231:293-298

L Lodeiros CJ, Himmelman JH (1996) Influence of fouling on the growth and survival of the tropical scallop, Euvola (Pecten) ziczac L. 1758 in suspended culture. Aquacult Res 27:749-756

* Lodeiros C, Himmelman JH (2000) Identification of factors affecting growth and survival of the tropical scallop Euvola (Pecten) ziczac in the Golfo de Cariaco, Venezuela. Aquaculture 182:91-114

Lodeiros C, Freites L, Nuñez M, Himmelman JH (1993) Growth of the Caribbean scallop Argopecten nucleus (Born, 1970) in suspended culture. J Shellfish Res 12: 291-294

* Lodeiros C, Rengel J, Freites L, Morales F, Hilmmelman JH (1998) Growth and survival of the tropical scallop Lyropecten (Nodipecten) nodosus maintained in suspended culture at three depths. Aquaculture 165:41-50

Lodeiros C, Rengel JJ, Himmelman JH (1999) Growth of Pteria colymbus (Röding, 1798) in the Golfo de Cariaco, Venezuela. J Shellfish Res 18:155-158

Lodeiros C, Rengel J, Guderley HE, Nusetti O, Hilmmelman JH (2001) Biochemical composition and energy allocation in the tropical scallop Lyropecten (Nodipecten) nodosus during the months leading up to and following the development of gonads. Aquaculture 199:63-72

* Mendoza Y, Freites L, Lodeiros CJ, López JA, Himmelman $\mathrm{JH}$ (2003) Evaluation of biological and economical aspects of the culture of the scallop Lyropecten nodosus in suspended and bottom culture. Aquaculture 221:207-219

* Pacheco A, Garate A (2005) Bioincrustantes en estructuras de cultivo de Argopecten purpuratus en Bahía Samanco, Perú. Ecol Apl 4:149-152

Perera M, Ballesteros M, Turon X (1999) Estudio de los organismos epibiontes en un cultivo de bivalvos marinos del delta del Ebro. Cah Biol Mar 31:385-399

* Pérez E, Lodeiros C, Semidey D, Uribe E, Freites L (2016) Crecimiento, supervivencia e influencia de factores ambientales en tres cohortes de la ostra perla Pinctada imbricata, en cultivo suspendido en el Golfo de Cariaco, Venezuela. Lat Am J Aquat Res 44:99-112

* Pit JH, Southgate PC (2003) Fouling and predation; how do they affect growth and survival of the blacklip pearl oyster, Pinctada margaritifera, during nursery culture? Aquacult Int 11:545-555 
Roma RPCR, de Almeida-Marques HL, Stojanov-Bueno R (2009) Controle biológico de organismos incrustantes em um cultivo de vieiras Nodipecten nodosus (Linnaeus, 1758) em Ubatuba, SP, Brasil. Biotemas 22:107-115

Román G, Campos MJ, Acosta CP, Cano J (1999) Growth of the queen scallop (Aequipecten opercularis) in suspended culture: influence of density and depth. Aquaculture 178:43-62

Román G, Louro A, De La Roche JP (2003) Intermediate culture of king scallop (Pecten maximus) in suspension in cages: effect of stocking density and depth. J Shellfish Res 22:647-654

Rupp GS (2007) Cultivo de vieira Nodipecten nodosus em Santa Catarina: influência da profundidade, densidade e freqüência de limpeza. Bol Téc Epagri Santa Catarina 135:1-82

Strickland JDH, Parsons TR (1972) A practical handbook of seawater analysis, 2nd edn. Bull Fish Res Board Can 167

Uribe E, Lodeiros C, Felix-Pico E, Etchepare I 2001 Epibiontes en pectínidos de Iberoamérica. In: Maeda-Martínez AN (ed) Los moluscos pectínidos de Iberoamérica: ciencia y acuicultura. LIMUSA, Mexico City, p 249-266

Valderrama D, Velasco LA, Quiroz N (2016) Economic assessment of hatchery production of Argopecten nucleus spat to support the development of scallop aquaculture in the Wider Caribbean. Aquacult Rep 4:169-177

*Velasco LA (2006) Effect of microalgal concentration and water temperature on the physiology of the Caribbean scallops Argopecten nucleus and Nodipecten nodosus. J Shellfish Res 25:823-831

Velasco LA (2008) Biología y cultivo de los pectínidos de interés comercial de Colombia. Fondo de Publicaciones de la Universidad del Magdalena, Santa Marta

Velasco LA, Barros J (2007) Potential of hatchery broodstock conditioning of the Caribbean scallops Argopecten nucleus and Nodipecten nodosus. Aquaculture 272:767-773

Velasco LA, Barros J (2008) Experimental larval culture of the Caribbean scallops Argopecten nucleus and Nodipecten nodosus. Aquacult Res 39:603-618

Velasco LA, Barros J (2009) Survival and growth of hatchery-

Editorial responsibility: Philippe Archambault,

Rimouski, Québec, Canada produced postlarvae and spat of the Caribbean scallops Argopecten nucleus and Nodipecten nodosus. Aquacult Res 40:362-375

*Velasco LA, Barros J (2010) Spat collection and experimental culture of the Atlantic pearl oyster, Pinctada imbricata (Bivalvia: Pteriidae), under suspended conditions in the Caribbean. J World Aquacult Soc 41:281-297

Velasco LA, Borrero FJ (1996) Cultivo experimental de la ostra perlífera alada Pteria colymbus (Bivalvia: Pteriidae) en el Caribe colombiano. In: Silva A, Merino G (ed) Acuicultura en Latinoamérica, comunicaciones cortas IX Congreso Latinoamericano de Acuicultura, Coquimbo, 15-18 October 1996, Asociación Latinoamerica de Acuicultura, p 224-231

Velasco LA, Borrero FJ (2004) Captación de semilla y cultivo experimental del hacha Pinna carnea (Mollusca: Bivalvia) en el Parque Nacional Natural Tayrona, Caribe colombiano. Intropica 1:75-83

Velasco LA, Barros J, Acosta E (2007) Spawning induction and early development of the Caribbean scallops Argopecten nucleus and Nodipecten nodosus. Aquaculture 266:153-165

Velasco LA, Barros J, Guerrero A (2009) Growth and survival of the Caribbean scallops Argopecten nucleus and Nodipecten nodosus in suspended culture at the Taganga Bay, Colombia. Aquacult Res 40:687-695

Velasco LA, Barros J, Trujillo C, Gómez J, Arias LM, Hernández R, Rojas J (2011) State of shellfish aquaculture on the Caribbean coast of Colombia and potential site for a regional hatchery facility. In: Lovatelli A, Sarkis S (eds) A regional shellfish hatchery for the Wider Caribbean: assessing its feasibility and sustainability. FAO Regional Technical Workshop, Kingston. FAO Fish Aquacult Proc No. 19. FAO, Rome, p 119-132

Velasco LA, Barros JM, Carrera S, Barbosa W, Barreto A (2013) Alliance between university and artisanal fishermen: a model for Caribbean scallops culture in Colombia. In: 19th Int Pectnid Workshop, Florianápolis

*Ventilla RF (1982) The scallop industry in Japan. Adv Mar Biol 20:310-382

Submitted: June 13, 2019; Accepted: September 5, 2019

Proofs received from author(s): October 17, 2019 